\title{
A presença da fala na melodia do rap*
}

\author{
MARCELO SEGRETO*
}

\begin{abstract}
RESUMO: Neste artigo, examinaremos a presença da fala e dos processos de musicalização na melodia do rap. Estudaremos as explorações mais radicais da lingua oral com a inserção de falas diretas, sem qualquer estabilização musical. Faremos uma descrição detalhada das divisões rítmicas mais comuns no canto dos $M C^{\prime}$ 's e observaremos exemplos em que se destaca o uso de registros diferentes de altura. Analisaremos ainda a presença da fala na história do gênero e de que maneira essa predominância da língua oral no rap está intimamente ligada a seu caráter de denúncia, à relação entre o rapper e o público e à relação entre o compositor e a obra.
\end{abstract}

PALAVRAS-CHAVE: Música popular; Canção popular; Rap.

\section{The Presence of speech in the Rap's Melody}

ABSTRACT: In this paper, we will discuss the melody of rap music and your relationship with the oral language. We will analyze the rhythmic patterns of rap, the bit of instrumental arrangements and significant changes in the frequency parameter observed in the melodies created by MCs. We believe that there are musical issues (generally ignored by researchers) that could help us to understand more deeply the music practiced by rappers. Add to that, we will show how these oral elements often have a relation to the social content of the lyrics.

KEYWORDS: Popular music; Popular song; Rap.

\footnotetext{
* Este artigo é uma adaptação do primeiro capítulo da dissertação de mestrado "A linguagem cancional do rap", de minha autoria, defendida em fevereiro de 2015 no Departamento de Linguística da Faculdade de Filosofia, Letras e Ciências Humanas da Universidade de São Paulo (FFLCH-USP).

${ }^{*}$ Marcelo Segreto é formado em Música (composição) pela ECA-USP e em Letras pela FFLCH-USP. É Mestre em Semiótica e Linguística Geral sob orientação do Prof. Dr. Luiz Tatit com dissertação sobre a linguagem da canção rap. Atualmente, cursa doutorado com o mesmo orientador, desenvolvendo trabalho sobre a presença da fala na composição de canções. É o idealizador, compositor e arranjador do grupo Filarmônica de Pasárgada com o qual lançou os CDs O hábito da força (2012), Rádio Lixão (2014) e Algorritmos (2016). E-mail: marcelosegreto@yahoo.com.br
} 


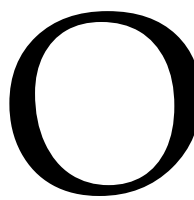

rap é, sem dúvida, um dos gêneros artísticos mais presentes na cultura brasileira atual. A discussão em torno do esgotamento da canção popular, levantada pelo compositor Chico Buarque em dezembro de 2004, estava centrada no aparecimento do rap. Atualmente, ele ocupa um importante espaço na mídia e a todo o momento surgem novos grupos e MC's. Além disso, o modo como esses cancionistas abordam os temas da violência e da injustiça social nas grandes cidades, sob a perspectiva da população pobre e com forte postura de confronto, é fato inédito na história da arte brasileira ${ }^{2}$. Por tudo isso, acreditamos na importância de uma investigação mais sistemática da sua linguagem. Ao longo deste artigo, desejamos realizar associações significativas entre as questões frequentemente levantadas pelos estudos historiográficos e sociológicos e os aspectos composicionais do rap. Isto é, pretendemos detectar no próprio artesanato do gênero a sua força social.

A presença da fala no rap é certamente uma das características mais evidentes para o ouvinte. Ela é tão marcante que dificilmente encontramos uma canção do gênero que não possua, além do usual "canto falado" mais estabilizado ritmicamente, inserções de falas "diretas", sem qualquer tipo de musicalização. Se tomarmos como exemplo os seis discos de estúdio ${ }^{3}$ do maior grupo de rap brasileiro, os Racionais $\mathrm{MC}^{\prime}$ s, constataremos que em pouquíssimas canções não encontraremos nenhum trecho de fala direta ${ }^{4}$. São diálogos entre os rappers, conversas telefônicas e sons de vozes simulando cenas de violência ou ilustrando determinadas situações. Nesses momentos, o uso da fala é explorado de modo radical. Em 12 de outubro (2002), por exemplo, ouvimos uma faixa composta unicamente pela voz falada de Mano Brown. É quando a fala apresenta-se pura, em estado bruto. Observamos a ocorrência de hesitações, redundâncias e reformulações típicas da língua oral. Na transcrição abaixo, o rapper relata a ocasião em que encontrou com crianças de uma comunidade pobre e indagou sobre os seus estudos.

\footnotetext{
2 Ainda que possamos observar esse caráter de denúncia nas letras de gêneros como o samba, por exemplo, acreditamos que o rap adota uma postura contestatória mais incisiva justamente pela especificidade de sua forma artística. Discutiremos essa questão adiante.

${ }^{3}$ Holocausto urbano (1990), Escolha o seu caminho (1992), Raio X Brasil (1993), Sobrevivendo no inferno (1997), Nada como um dia após o outro (2002) e Cores $\mathcal{E}$ valores (2014).

${ }^{4}$ São elas a sexta faixa do CD Sobrevivendo no inferno (faixa instrumental) e as quatro canções iniciais do $\mathrm{CD}$ Cores $\mathcal{E}$ valores que consistem em três canções de pequena duração e uma faixa instrumental.
} 
- E aí mano, e aí? Tá estudando?

Tal... Aí o moleque falou assim:

- Esse aqui hoje xingou a mãe dele.

Aí eu falei assim:

- Por que você xingou sua mãe?

- Ah, porque...

Não! Nem foi isso... Ele falou assim... Eu falei...

Vocês ganharam presente? Eu perguntei. Não foi não, Neto?

Vocês ganharam presente? Ele falou:

- Eu ganhei foi tapa na cara hoje.

O fundo musical que acompanha o texto é ritmicamente instável, composto por frases musicais tocadas ao violão sem padrões rítmicos marcados, com pulso indefinido ou variável e sem nenhuma preocupação em formar uma base regular para o rapper. Acreditamos que essa característica da base também favorece a falta de musicalização do texto. É interessante destacar que todas essas ocorrências típicas da fala não foram eliminadas do fonograma. Isto é, a instabilidade entoativa é parte integrante de sua criação. Quando comparamos o rap com gêneros estilisticamente próximos, como o samba de breque, notamos que esses fenômenos orais dificilmente se dão fora do universo do hip hop. Tanto o MC quanto o sambista trabalham a melodia de maneira entoativa e criam partes faladas que se intercalam às partes cantadas. Ou seja, os dois gêneros estão tão próximos da língua oral que permitem de forma muito natural e até mesmo imperceptível a inserção de trechos falados, às vezes sem qualquer nível de musicalização. No entanto, no samba de breque, observamos construções mais estabilizadas que, muitas vezes, transformam-se em bordões que provavelmente serão repetidos por todos os intérpretes que cantarem a obra 5 . Diferentemente, 12 de outubro dificilmente será fielmente repetida por outro intérprete. Se isso ocorrer, provavelmente a estará imitando e não a reinterpretando.

Em V.L parte 2 (2002) notamos uma construção similar. Ao final da canção, a voz de Mano Brown se apresenta apenas parcialmente musicalizada. Ainda verificamos a presença de rimas, mas o texto não é entoado com uma configuração rítmica regular, como observamos no restante da obra. Nesse trecho, as sílabas não são pronunciadas sincronicamente em relação aos ataques rítmicos da base. Assim, a regularidade musical é minimizada tendo em vista a instabilidade da emissão.

${ }^{5}$ Por exemplo, a conhecida canção Minha Palhoça (J. Cascata) de 1933. 
Porque o guerreiro de fé nunca gela

Não agrada o injusto e não amarela

O rei dos reis foi traído e sangrou nessa terra

Mas morrer como um homem é o prêmio da guerra

Mais ó, conforme for, se precisar afogar no próprio sangue, assim será

Nosso espírito é imortal, sangue do meu sangue

Entre o corte da espada e o perfume da rosa

Sem menção honrosa, sem massagem

A vida é loka nego e nela eu tô de passagem

A Dimas, o primeiro, saúde guerreiro, Dimas

Constatamos, então, que a presença da língua oral no rap não se restringe ao canto do MC. Há também a exploração direta da fala e, muitas vezes, como é caso da canção 12 de outubro, certos trechos são executados com tamanha espontaneidade que trazem marcas conversacionais típicas da língua oral. Perguntamo-nos então o porquê da presença desses textos com pouquíssimo nível de musicalização. Como veremos, acreditamos que a importância da comunicação da mensagem para o rapper faz com que os $\mathrm{MC}^{\prime}$ s não se contentem com o uso da fala ritmada. Ou seja, é preciso dizer o texto de maneira ainda mais direta, fato curioso para um gênero que já explora fortemente a fala. Nesses trechos, essa exploração é realizada de modo bastante radical. Se escutarmos atentamente todo esse repertório, contudo, constataremos que há uma nítida diferença entre os exemplos acima e a composição dos $\mathrm{MC}^{\prime}$ s propriamente dita. Mesmo que intuitivamente, o ouvinte tem plena consciência de quando o rapper canta a letra e quando emite falas não musicalizadas. Por exemplo, percebemos facilmente a diferença entre as canções 12 de outubro e V.L parte 2 e os trechos transcritos abaixo (Ex. 1 e Ex. 2).

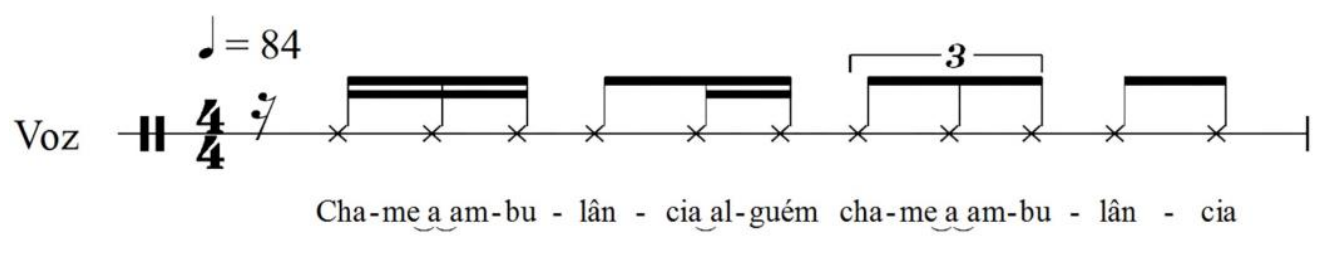

Ex. 1 - Voz de Ice Blue em Rapaz Comum (RACIONAIS MC'S, 1998) 


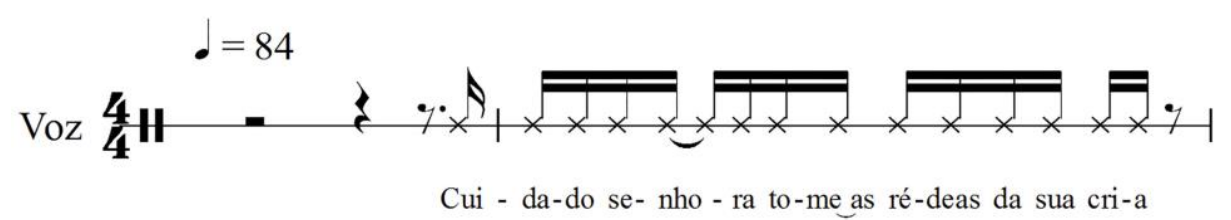

Ex. 2 - Periferia é periferia (em qualquer lugar)... (RACIONAIS MC'S, 1998)

Nesses exemplos, não é o cantor principal quem entoa os versos, mas sim a voz de um segundo MC que interage com o canto do primeiro vocalista. No rap, muitas vezes, esse tipo de ocorrência aparece na forma de uma fala direta, sem estabilização rítmica. Aqui, contudo, observamos algum nível de musicalização. Em Rapaz comum, esse nível é tão mínimo que não sabemos ao certo se Ice Blue está cantando ou simplesmente falando a frase "chame a ambulância, alguém chame a ambulância!". Sentimos, porém, a entoação perfeita de um pedido de socorro, ainda que realizado com um padrão rítmico determinado, isto é, com um teor mínimo de musicalização. Destacamos a mesma situação em Periferia é periferia (em qualquer lugar)... na qual observamos uma maior preocupação com a estabilidade musical. A frase "cuidado senhora, tome as rédeas da sua cria" apresenta uma configuração rítmica regular e também estabelece uma rima com a última palavra do verso anterior entoado pelo cantor principal da faixa ("Herdeiro de mais alguma dona Maria"). Constatamos, então, que é parte integrante do trabalho artístico dos $\mathrm{MC}^{\prime} \mathrm{s}$ a possibilidade de optar por diferentes níveis de musicalização do texto, ora realizando uma fala mais explícita, ora uma entoação mais ritmada. Desse modo, começamos a perceber as nuances da presença da língua oral no rap, notando a existência de variados graus entoativos. Nesse momento, acreditamos ser necessária uma observação mais detalhada sobre a constituição da melodia do rap, isto é, dos versos rimados e ritmados (que é o que primeiramente caracteriza a música do hip hop) 6 . Além disso, desejamos sublinhar um fato curioso que frequentemente ocorre na sua recepção, devido à força do processo entoativo: acostumado com o repertório das canções tonais, o ouvinte encontra no rap tanta instabilidade e proximidade com a fala

\footnotetext{
${ }^{6}$ É comum que a denominação "rap" seja aplicada apenas às partes cantadas com ritmo. Os trechos falados, os samples inseridos pelos DJ's e os refrãos estabilizados muitas vezes não são considerados como sendo rap propriamente dito.
} 
que, muitas vezes, não o considera nem mesmo um gênero musical. Examinemos essa questão com maior cuidado.

No rap predominantemente encontramos um texto verbal entoado com certa regularidade rítmica. A emissão das sílabas do texto cantado coincide com os ataques percussivos da base ou com subdivisões regulares dos pulsos sugeridas pelo arranjo. Isso já significa um primeiro nível de musicalização, pois, na língua oral, raramente encontramos um ritmo regular. Ao examinarmos grande parte da produção do rap brasileiro, pudemos constatar que todos apresentam praticamente o mesmo padrão rítmico. Majoritariamente, observamos a subdivisão binária da pulsação. As sílabas da letra subdividem o pulso em quatro partes (figura abaixo). Assim, ainda que tenhamos a forte presença da língua oral, notamos o apoio de elementos musicais fundamentais para a composição dos $\mathrm{MC}^{\prime}$ s. Caso contrário, qualquer discurso verbal poderia ser uma canção. No exemplo seguinte (Ex. 3), percebemos claramente a existência de uma forma musical ordenadora que distingue o rap da fala coloquial.

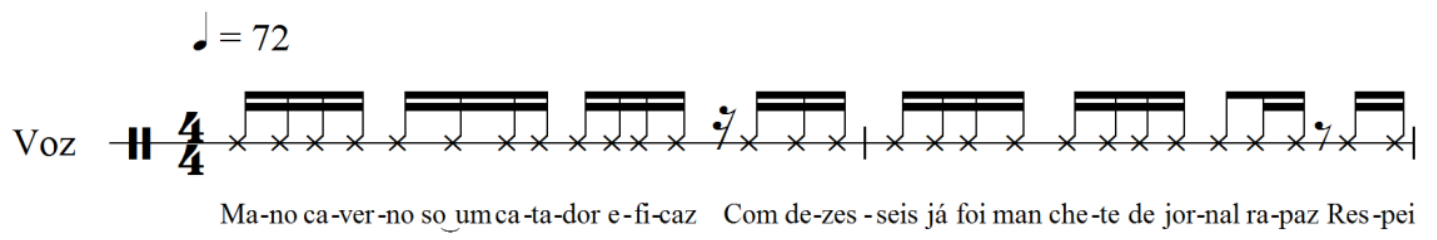

Ex. 3 - Rap é compromisso (SABOTAGE, 2001)

Além disso, essa configuração rítmica pode ser sutilmente alterada por meio de inflexões realizadas pelo $\mathrm{MC}$ a partir do acento tônico das palavras que compõem a letra. No próximo exemplo (Ex. 4), a subdivisão binária do pulso em quatro semicolcheias é transformada pelas acentuações do texto verbal enfatizadas pelo cantor. Os versos "para os manos daqui", "para os manos de lá" e "negro pra negro será" passam, então, a receber uma acentuação ternária. 


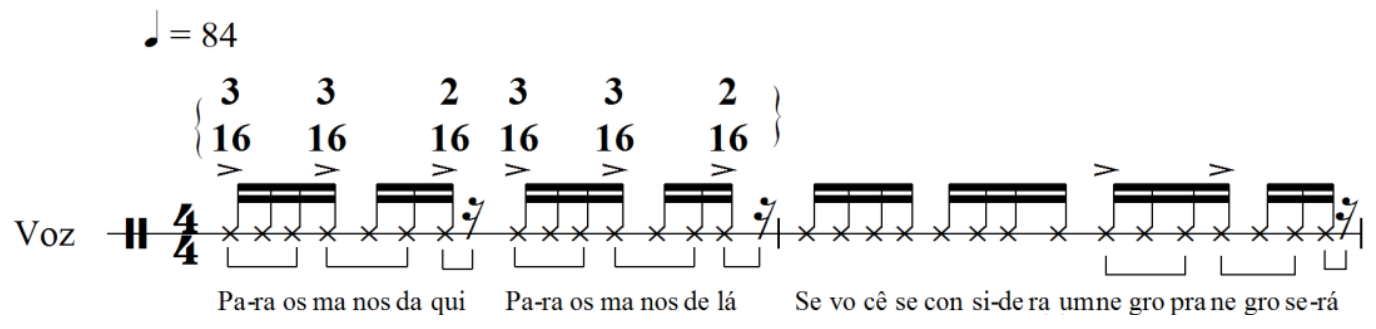

Ex. 4 - Voz ativa (versão rádio) (RACIONAIS MC'S, 1992)

Em Capítulo 4, versículo 3 (Ex. 5), constatamos o mesmo tipo de configuração, com a predominância das subdivisões em quatro partes e momentos específicos com variação de acento ternário.

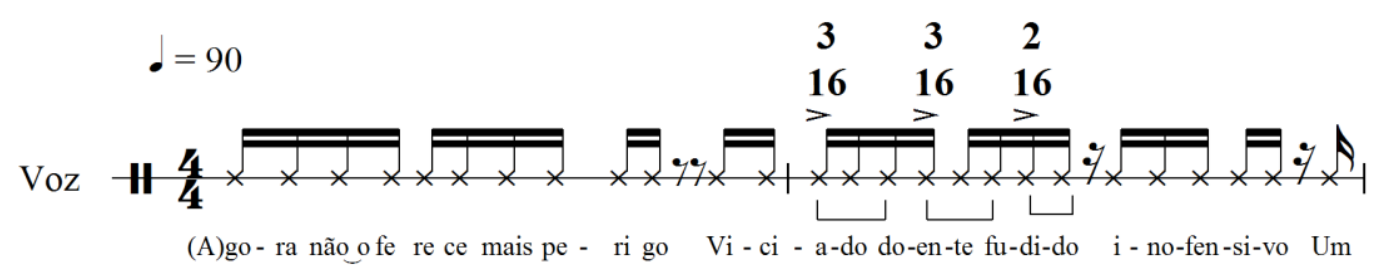

Ex. 5 - Capítulo 4, versículo 3 (RACIONAIS MC'S, 1998)

Ademais, também encontramos a seguinte variação: ao invés da subdivisão regular em quatro semicolcheias, podemos observar a intercalação de figuras pontuadas e simples. Os quatro ataques por unidade de tempo são mantidos. As durações, no entanto, passam a sofrer variações na medida em que ocorre a alternância entre as sílabas longas (L) e as sílabas breves (B).

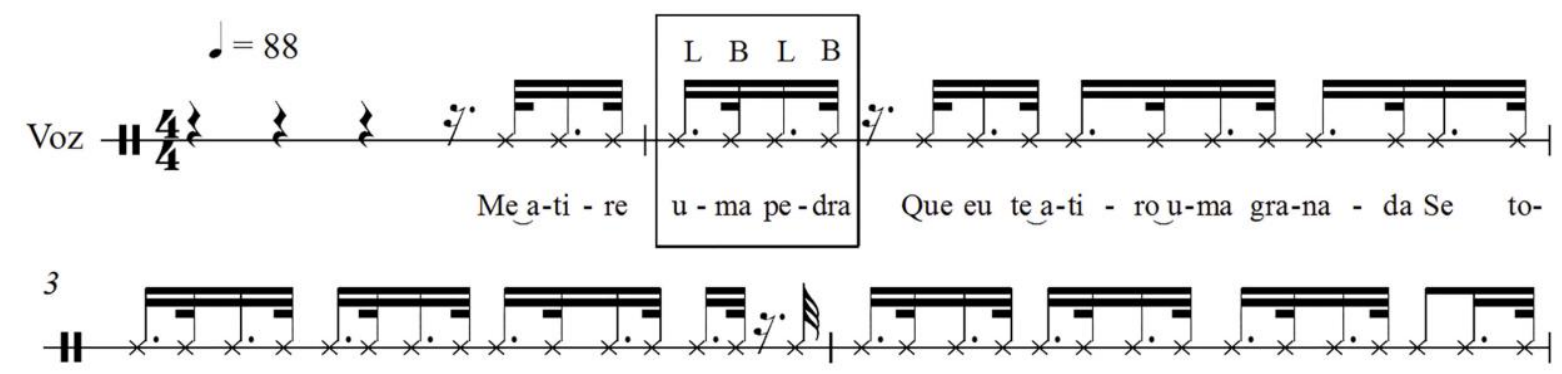

car em mi-nha fa-ce su - a vi-da es-tá dse-la-da Por - tan-to meu-a-mi-go pen-se bem no que fa-rá Pois não

Ex.6 - Corpo fechado (Thaíde e DJ Hum) 


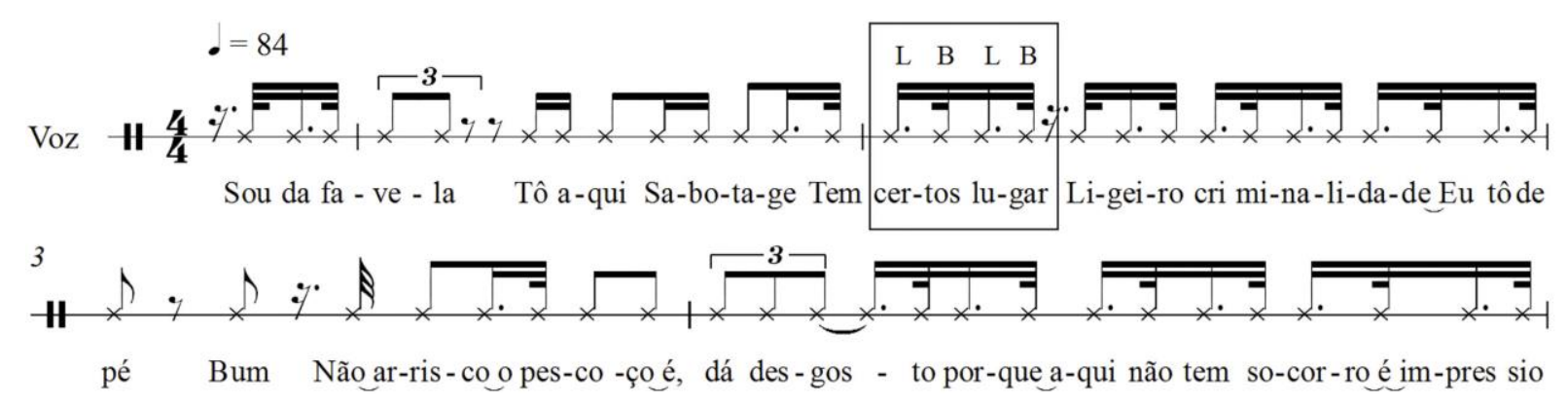

Ex.7 - Respeito é pra quem tem (Sabotage)

Em ambos os fragmentos (Ex. 6 e Ex. 7), as sílabas que recaem sobre as notas pontuadas duram mais do que as que recaem sobre as notas simples. Geralmente, essas figuras pontuadas correspondem às sílabas tônicas dos vocábulos. Em Corpo fechado, por exemplo, notamos que apenas a palavra "uma" não é cantada com a nota pontuada recaindo sobre sua sílaba tônica. Assim, constatamos que essas durações alongadas representam, além de um balanço rítmico desejado pelo rapper, um apoio entoativo ligado à entoação da fala. Por um lado, a alternância entre as figuras longas e breves produz na canção um interesse marcadamente musical. Por outro, adapta-se perfeitamente ao revezamento entre as sílabas tônicas e átonas presentes na língua oral. Detectamos, aqui, uma interessante combinação entre a música e a fala.

Enfim, no rap, ora observamos a divisão regular da letra em quatro semicolcheias, ora a divisão alternada com figuras pontuadas e simples. Há, portanto, no canto dos $\mathrm{MC}^{\prime}$ s, uma significativa uniformidade rítmica que, por sua vez, não se dá somente em relação à melodia vocal. Em geral, a velocidade da pulsação no rap também varia muito pouco. Na tabela abaixo (Ex. 8) registramos os andamentos de todas as canções que formam os seis álbuns de estúdio do grupo Racionais MC's. 


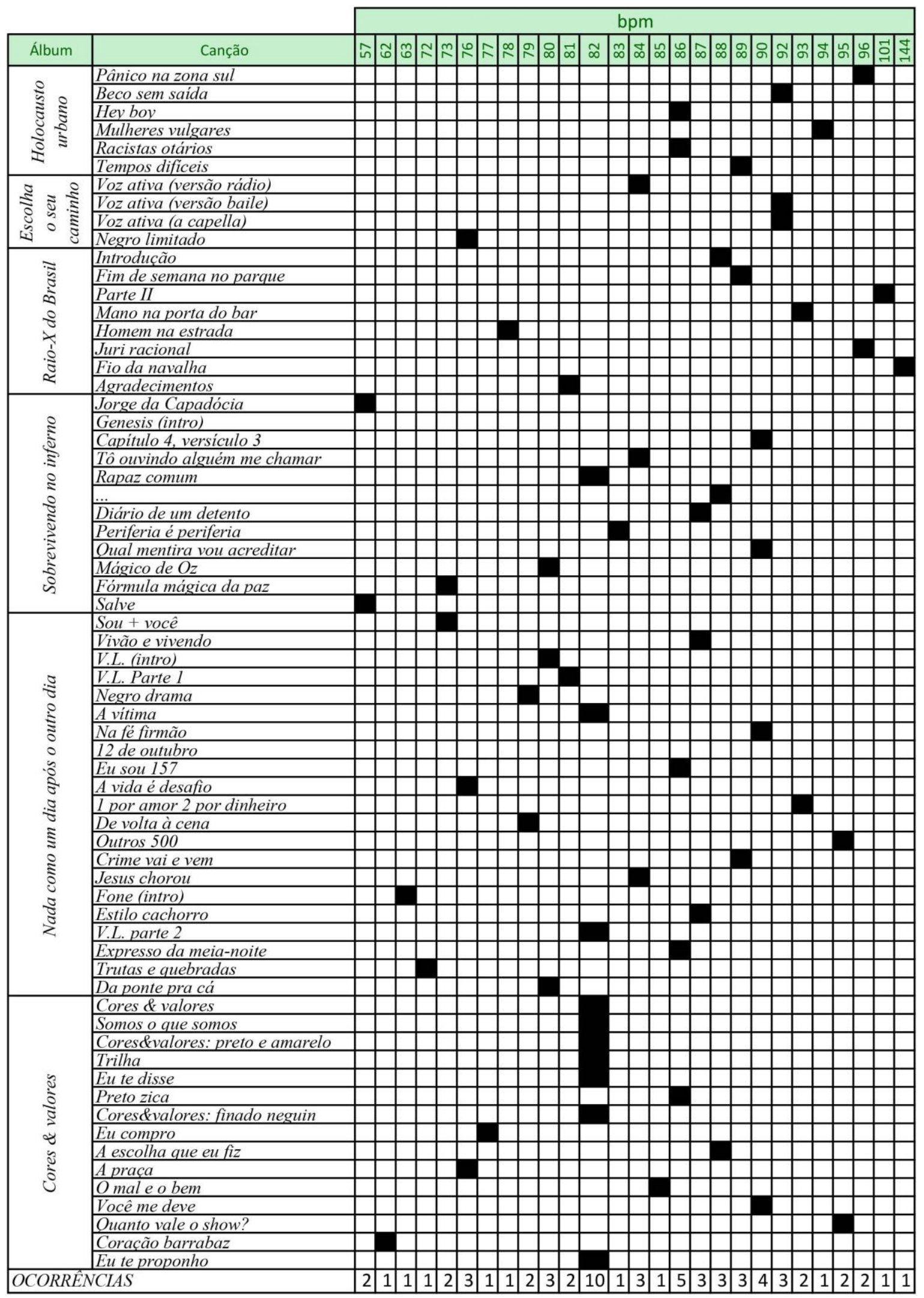

Ex. 8 - Velocidade da pulsação nas canções dos Racionais $M C^{\prime}$ s 
Analisando a tabela acima, podemos verificar que os andamentos das canções estão localizados predominantemente entre 73 e 96 batimentos por minuto. Supomos que essa restrição em relação ao andamento favorece a uniformidade observada na subdivisão rítmica da letra. Ou seja, essa faixa restrita de velocidade do pulso faz com que o MC naturalmente tenda a entoar a letra de modo que as subdivisões das sílabas sejam predominantemente quatro por unidade de tempo. Essa configuração, por sua vez, parece ser ideal para se cantar o rap de maneira "eficaz". Expliquemos. Se o andamento da base for muito rápido, a compreensão do texto pode se perder, o que será prontamente rejeitado por cancionistas que tanto prezam a comunicação com o ouvinte. Por outro lado, se o arranjo for demasiadamente lento, o caráter mais incisivo do canto pode ficar comprometido: o texto passaria a ser emitido com duração mais alongada do que o desejável para o tipo de mensagem transmitida pelos rappers.

Nesse sentido, é significativo notar que, por vezes, os DJ's alteram o andamento das bases sampleadas para adequar a velocidade da pulsação ao canto do MC. Como sabemos, grande parte dessas bases vem do repertório da soul music dos anos 1960 e 1970. Na canção Pânico na zona sul dos Racionais MC's, por exemplo, o DJ KL Jay se apropria de Mind Power de James Brown para compor o seu arranjo. Mas a música do cantor norte-americano tem o bpm em 104 e a faixa dos Racionais MC's em 96. Ou seja, o DJ alterou em oito pontos para baixo a velocidade da pulsação para que o acompanhamento rítmico ficasse mais lento e adequado ao canto dos rappers. $\mathrm{O}$ mesmo é observado em Tempos dificeis (bpm 89), do mesmo grupo, que utiliza a base de Papa Don't Take No Mess (bpm 97) também de James Brown. Nesse caso, podemos escutar claramente a diminuição no andamento realizada pelo DJ e a consequente alteração da altura dos instrumentos harmônicos e melódicos que compõem o arranjo original. Ao diminuir a velocidade da canção, a frequência geral da faixa também se alterou para o grave. É relevante constatar a coexistência das tendências musicais e entoativas ligadas a essa característica do rap. Isto é, se, por um lado, as bases rítmicas procedem do repertório da soul music (com padrões rítmicos bem regulares de músicas ligadas à dança), por outro, a sua velocidade é alterada para favorecer a entoação do texto cantado pelo rapper. 
Enfim, percebemos a existência de uma padronização do parâmetro musical da duração em praticamente todas as canções do gênero. Primeiramente, constatamos que o ritmo adotado é predominantemente a subdivisão de cada pulsação em quatro partes (quatro semicolcheias ou quatro figuras pontuadas e simples). Depois, verificamos que a velocidade da pulsação se situa entre 73 e 96 bpm. Dessa maneira, podemos afirmar que a melodia do rap apresenta uma significativa estabilidade sonora. Sendo assim, por que sentimos tanta fala no rap? Ou melhor, se podemos comprovar essa marcante estabilidade sonora, por que é tão disseminada a ideia de que a entoação (fator de instabilidade musical) é um elemento tão característico do gênero? Pois bem, acreditamos que a forte presença da língua oral se deve não somente ao fato de o canto do MC se situar em uma região de frequência próxima à da voz falada. Supomos que a própria estabilidade rítmica comentada acima, contraditoriamente, também favorece o caráter entoativo do rap. Isto é, se todas essas canções atuam ritmicamente com a divisão do pulso em quatro partes e com andamento restrito, logo, o ouvinte deixa de sentir identidades rítmicas relevantes, como se não percebesse os motivos musicais. É como se escutássemos o rap como uma massa de falas homogêneas, sem forma musical. Assim, embora as sílabas cantadas pelos rappers sejam organizadas de modo regular no tempo, essa regularidade quase absoluta faz com que, paradoxalmente, o ouvinte não a perceba.

Obviamente, no entanto, o que mais contribui para a presença da fala no rap é o fato de a voz do $\mathrm{MC}$, ao contrário do canto nas canções tonais, não estabilizar a frequência em alturas que coincidem com as notas musicais. Não há a formação de melodias com alturas estáveis, nem diferenciações intervalares ou configurações de escalas da música tonal. A altura no rap é geralmente a altura da voz falada. Assim, podemos dizer que a melodia do rap não é tonal na medida em que não há ênfase nas relações acordais hierárquicas nem configurações melódicas estáveis o suficiente para que identifiquemos nas notas do canto relações de dominante e tônica, por exemplo. Há sim, muitas vezes, um sentido de tensão e resolução na emissão do cantor em diálogo com o fundo musical do DJ, porém, sem a estabilização da frequência.

Dito isso, devemos notar que, no rap, curiosamente, há ocorrências muito interessantes em relação ao parâmetro altura. Primeiramente, podemos examinar 
exemplos em que, partindo de uma instabilidade inicial de frequência, a voz se estabiliza e passa a realizar notas musicais reconhecíveis. Em V.L parte 2 (Ex. 9), constatamos variações de altura no canto do MC com uma ascendência para o agudo até a estabilização completa. Assim, a voz traça um caminho que parte da fala e chega à estabilização melódica. Vejamos esse exemplo de modo mais detalhado.

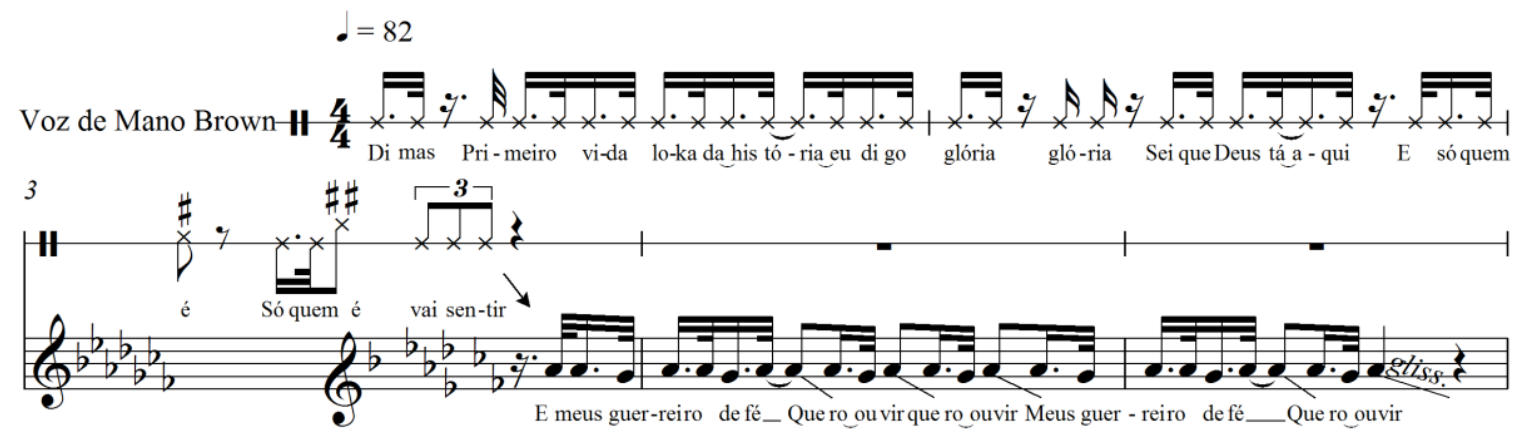

Ex. 9 - Voz de Mano Brown em V.L. Parte 2 (RACIONAIS MC'S, 2002)

Nos dois primeiros compassos Mano Brown canta com registro próximo ao da voz falada. No terceiro compasso, o rapper eleva um pouco a frequência quando canta a palavra "é" e, subitamente, se mantém no agudo realizando uma melodia perfeitamente estabilizada, ao passear pelas notas Lá bemol e Sol bemol sobre uma base harmônica claramente tonal, em Lá bemol menor. Na sequência, temos um refrão totalmente estabilizado na altura e no ritmo: "Preparado pra morrer nóis é, certo é, certo é, dê no que der". Nessa mesma canção há outro momento relevante. Na figura abaixo (Ex. 10), constatamos que Mano Brown altera significativamente a altura de sua emissão. $\mathrm{O}$ MC inicia a letra em uma tessitura grave e a partir de certo instante passa a cantar em região mais aguda. Em seguida, repentinamente volta para a região grave. Observando a letra do rap, notamos que a altura da voz se desloca para o agudo na medida em que o discurso se torna mais inflamado. Assim, parece-nos que a elevação da frequência corresponde a um crescimento da tensão na enunciação. 


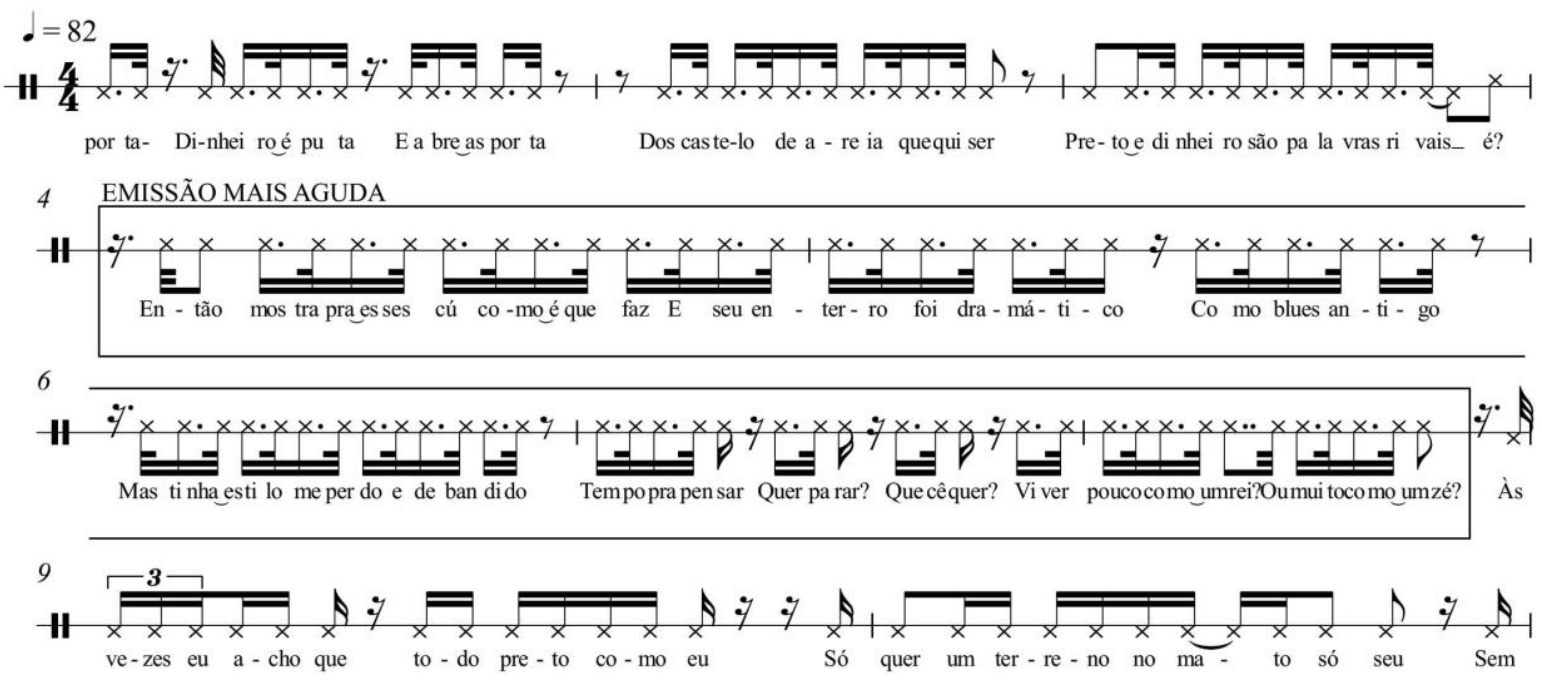

Ex. 10 - V.L. Parte 2 (RACIONAIS MC'S, 2002)

No trecho destacado (Ex. 10, compassos 4 a 8), a voz sobe nitidamente na altura, contrastando com a emissão mais grave que surge a partir do compasso 9. São duas maneiras diferentes de entoar a letra, encontradas em muitas interpretações de Mano Brown. No exemplo acima, coexistem numa mesma canção. Esse contraste parece ser uma característica vocal do cantor. É a oposição entre a sua emissão grave que ouvimos em Diário de um detento e a sua emissão mais aguda que escutamos em Negro drama, por exemplo. Essa diferença na altura, no entanto, não faz com que o sentido entoativo da canção se perca. Como comentamos acima, a frequência mais aguda pode ser indício de uma fala mais nervosa, de uma emissão mais intensa e agressiva. Como alguém que, irritado, sobe o tom de voz para falar mais enfaticamente. Assim, embora tenhamos essas configurações ligadas à musicalização da letra (formação de certos padrões rítmicos e conformações diferenciadas de frequência), notamos que a fala ainda assim prevalece sobre a música, sendo o aspecto que mais chama a atenção do ouvinte. 


\section{A história do hip hop e a sua relação com a fala}

A importância do texto verbal faz parte do universo do rap desde sua origem. No Bronx, bairro pobre de Nova York onde o hip hop nasceu, imigrantes jamaicanos organizavam festas nas quais utilizavam os chamados sounds systems, potentes equipamentos de som acoplados a carrocerias de caminhão nos quais eram tocados discos de reggae, funk e soul. Os responsáveis pela execução musical eram chamados DJ's, em referência aos disc-jóqueis dos programas radiofônicos. Curiosamente, além de cuidarem do repertório da festa, os DJ's também falavam com o público por meio de um microfone, com o intuito de animar os participantes. Posteriormente, essa função passa a ser realizada pela figura do MC, abreviação de "mestre de cerimônia" (TEPERMAN, 2011, p.20). Assim, percebemos a coexistência, desde os primórdios do rap, das partes tocadas do DJ e das partes faladas do MC.

A própria repercussão do gênero norte-americano recém-chegado ao Brasil também nos indica o quanto a sua característica fortemente entoativa chamava a atenção de todos. Em 1979, o produtor, ator e cantor Luís Carlos Miele grava Melô do Tagarela, uma paródia de uma canção de grande sucesso internacional, Rapper's Delight, do grupo estadunidense Sugarhill Gang. A música é por vezes considerada como a primeira canção brasileira do gênero. Miele utiliza trechos do arranjo instrumental da versão americana e imita o seu canto falado apelidando-o de "tagarela". Assim, somente pelo título dado à versão brasileira, já podemos verificar o quanto a presença da língua oral sempre foi a marca principal desse tipo de canção.

Há muitas pesquisas etimológicas relacionadas à palavra rap. Em todas elas, observamos igualmente essa ligação com a fala. A origem mais aceita e difundida é a que identifica no vocábulo "rap" uma sigla para a expressão rhythm and poetry. Aqui, não há qualquer menção à altura ou às notas musicais. Portanto, o gênero se definiria como a junção entre um ritmo e um texto verbal. Há igualmente a tendência de se comparar o rap às variações de gêneros nordestinos como o repente e a embolada (canções muito entoativas) 7 . Há ainda quem defenda que o significado da sigla seja

\footnotetext{
7 Ver TEPERMAN, 2011, p.117
} 
"revolução através das palavras" (novamente a palavra à frente da música). Por fim, há explicações etimológicas ligadas aos concursos verbais e desafios cantados. Lembramos que o vocábulo rap já estava dicionarizado na língua inglesa desde o século XIV, como um verbo com sentido de "bater" ou "criticar". Assim, nesses jogos verbais, a expressão talvez ganhasse o significado de "bater com as palavras". Práticas lúdicas como os toasts (longos relatos rimados geralmente de conteúdo violento e obsceno) e o the dozens ou dirty dozens ${ }^{8}$ (desafio verbal no qual os participantes fazem insultos uns aos outros, igualmente rimados) são indícios de outra possível origem para o termo ${ }^{9}$. Diante de tantas suposições em relação à origem do nome rap, interessanos somente assinalar que todas as explicações etimológicas elencadas acima destacam a forte presença do elemento verbal.

O sentido de "bater" ou "criticar" do vocábulo rap também demonstra a íntima ligação entre a presença da fala e a presença de um discurso de protesto. Isto é, começamos a perceber que a proximidade em relação ao registro da língua oral se adequa perfeitamente à transmissão das mensagens dos $\mathrm{MC}^{\prime}$ 's. Logo, não devemos analisar o rap sem considerar de alguma maneira o seu sentido político. A sua carga ideológica (a reclamação constante por melhores condições de vida para a população pobre) influi diretamente na constituição de sua forma artística: a pobreza de uma população fomenta a contestação e esse questionamento é mais eficiente quando realizado por meio de construções próximas à fala. Walter Garcia já havia discutido essa questão, utilizando o termo "figurativização"10 para representar esse processo: “Ora, se o propósito do Racionais é passar uma mensagem crítica por meio da letra, a figurativização é o recurso mais adequado para isso. E o rap é o estilo de canção no qual esse recurso é mais essencial" (GARCIA, 2003, p.59). Nesse sentido, é importante destacarmos na história do rap a sua ligação com a vida violenta das periferias das grandes cidades e com a afirmação dos direitos dos negros. Como mencionamos acima, é comum que estudiosos associem o nascimento do gênero ao Bronx (bairro de Nova York localizado ao norte da ilha de Manhatann) no início da década de 1970. Na

\footnotetext{
8 Sobre esse assunto ver BÉTHUNE, 1999, p.139

9 Sobre esse assunto ver TEPERMAN, 2011, p.84

10 Esse termo pertence à teoria da semiótica da canção desenvolvida por Luiz Tatit e se refere à relação entre a melodia e letra que apresenta características da fala em sua construção. Ver TATIT, 2002.
} 
época, a região era habitada por uma população predominantemente negra que apresentava uma condição social extremamente precária, com altos índices de violência urbana, sobretudo com as frequentes disputas entre gangues rivais. Além disso, a sociedade americana ainda sofria as repercussões geradas pela atuação dos movimentos negros nos anos 1960. É nesse contexto fortemente político que se dá o nascimento do rap nos EUA. Eclode como uma consequência cultural das injustiças históricas sofridas pela população americana marginalizada: "Hip hop é uma forma cultural que tenta combinar as experiências de marginalização, as oportunidades brutalmente negadas e a opressão presente nos imperativos culturais da história, identidade e comunidade Afro-Americana e Caribenha" (ROSE, 1994, p.21).

Assim como no caso norte-americano, o rap brasileiro, desde sua origem, sempre se mostrou muito politizado ${ }^{11}$. No início dos anos 1980, o hip hop começa a se popularizar no Brasil em decorrência de seu sucesso internacional e, sobretudo, da dança break, presente em propagandas e programas televisivos. Em meados da década, começam a se reunir na estação São Bento do metrô de São Paulo, dançarinos de break (os chamados b-boys), frequentadores de bailes black da capital e simpatizantes do novo gênero de música americana. O local se torna o principal foco do movimento hip hop no Brasil, frequentado por artistas como Thaíde e DJ Hum e por integrantes do grupo Racionais MC's, todos ainda desconhecidos. Posteriormente, os praticantes de rap passam a se reunir na Praça Roosevelt. A estação São Bento se mantém como ponto de encontro dos dançarinos de break e os frequentadores mais interessados na música do hip hop e em suas questões políticas passam a visitar o novo local. É nesse novo espaço que surgem as primeiras posses brasileiras, organizações formadas por praticantes do hip hop em suas variadas formas artísticas. Nas posses, artistas e simpatizantes do movimento se reúnem com o objetivo de promover apresentações musicais, festas, eventos educativos, discussões e debates, sempre com o intuito de estimular a conscientização social do público. Entre as muitas organizações desse tipo que surgiram no Brasil, destaca-se a CUFA (Central Única das Favelas). Um de seus

\footnotetext{
${ }^{11}$ Refiro-me aqui aos grupos mais expressivos da música brasileira. Obviamente, há rappers que não apresentam em suas letras a temática do confronto social. Nesse momento, no entanto, como queremos estabelecer relações entre o processo figurativo e o conteúdo de protesto, interessa-nos, sobretudo, examinar os grupos que incluíram em seus raps mensagens politicamente engajadas.
} 
fundadores é o conhecido rapper MV Bill. Com o surgimento das posses, o hip hop e, sobretudo o rap, explicita e institucionaliza a sua propensão para a discussão política e denúncia. Dessa maneira, verificamos que essa tendência ideológica é componente fundamental para esse gênero de canção.

A questão política é tão proeminente que, muitas vezes, os estudiosos não chegam a discutir a forma artística adotada pelos compositores, considerando em suas análises apenas o conteúdo contestatório das letras. No limite, não haveria diferença entre estudar uma canção de Mano Brown ou uma entrevista do rapper na imprensa. Nesse artigo, no entanto, pretendemos examinar a matéria artística propriamente dita para que possamos encontrar a força política do rap na sua própria linguagem cancional. Primeiramente, é necessário investigar de que maneira essa linguagem (tão próxima à fala) torna-se um fator importante para o objetivo de conscientização política dos MC's. E, posteriormente, estudar de que forma a musicalização (a procura dos rappers por sonoridades estáveis com ritmos e rimas) também pode atuar em prol dessa mesma força política. Enfim, um discurso sem preocupação musical ou artística não possui o mesmo tipo de expressividade alcançado pelos raps. Todos sabemos que uma entrevista não substitui uma canção.

Tomando o primeiro aspecto como objeto de análise, podemos constatar que a maneira com que o MC traz à tona a questão social (denúncia geralmente realizada com afronta e agressividade) está intimamente relacionada a essa proximidade com a língua oral, sobretudo na forma combativa adotada na entoação da letra. Walter Garcia, ao analisar a canção Diário de um detento, ressalta o modo de dizer do rapper Mano Brown. Segundo o autor, essa maneira de dizer (a sua fala ofensiva) é um dado fundamental para o impacto gerado pelas canções do grupo.

Sobre a dicção de Mano Brown já foi dito, carrega agressividade. O modelo é norte-americano, mas a realização é brasileira. Ainda que o significado das palavras não fosse compreensível, seu jeito de cantar, ou mais propriamente, a matéria de sua voz afronta a humilhação a que negros são aqui submetidos historicamente. Na perspectiva do dominador, é a voz de um folgado que não tolera o seu lugar inferior no sistema social. (GARCIA, 2007, p.200) 


\title{
A identidade entre o rapper e o público, o compositor e a obra
}

O caráter entoativo (ou como prefere Tatit, "figurativo"), além de muito apropriado para o protesto, também propicia algo muito valorizado no universo do rap: a aproximação entre o artista e o público. Segundo Maria Rita Kehl, notamos no hip hop outro tipo de interação entre essas duas esferas. Há, nesse gênero, uma recusa em relação à separação extrema entre a massa de ouvintes e o artista excepcional. Critica-se até mesmo a ascensão social do artista negro ligada à lógica do mercado na qual alguns poucos indivíduos são aceitos e se transformam em objetos de veneração para uma "grande massa de fãs que sonham individualmente com a sorte de um dia também virarem exceção" (KEHL, 2000, p.211). O rap, ao contrário, procura se guiar a partir do lugar do semelhante. Dessa forma, os fãs de rap tendem a falar de igual para igual com seu ídolo, "como se cada um deles se considerasse um rapper em potencial" (KEHL, 2000, p.209).

\begin{abstract}
A força dos grupos de rap não vem de sua capacidade de excluir, de colocarse acima da massa e produzir fascínio, inveja. Vem de seu poder de inclusão, da insistência na igualdade entre artistas e público, todos negros, todos de origem pobre, todos vítimas da mesma discriminação e da mesma escassez de oportunidades (KEHL, 2000, p.226)
\end{abstract}

Essa proximidade comunicativa entre autor e público é tão marcante no rap que há casos em que ela constitui a própria canção. Curiosamente, nos álbuns do grupo Racionais $\mathrm{MC}^{\prime}$ s, notamos faixas compostas apenas por dedicatórias e agradecimentos falados pelos rappers com fundo musical do DJ, dirigidos às comunidades pobres e amigos espalhados pelo país. São exemplos as faixas Agradecimentos (1993), Salve (1998) e Trutas e quebradas (2002). Examinando a discografia dos grupos e rappers brasileiros mais importantes também encontramos diversas faixas de agradecimento ${ }^{12}$ : Salve as quebradas (De menos crime), Família G.O.G. agradece e Pode crê (GOG), Agradecido (MRN), Sem Esquecer as Favelas (MV Bill) e Salve (Sistema Negro). Além disso, encontramos diversas obras em que os $\mathrm{MC}^{\prime}$ s se dirigem diretamente ao público. É

\footnotetext{
12 Foram pesquisadas as discografias dos seguintes grupos e artistas: Consciência Humana, Criolo, Emicida, De menos crime, Facção Central, Faces do subúrbio, GOG, MRN, MV Bill, Posse Mente Zulu, Racionais MC's, RZO, Sabotage, Sistema Negro, SNJ, Thaíde \& DJ Hum e Xis.
} 
bastante comum encontrarmos nos discos de rap faixas introdutórias nas quais os cantores convidam diretamente seus ouvintes para a audição do álbum. Nesse sentido, ao observarmos as faixas iniciais dos discos dos Racionais $\mathrm{MC}^{\prime} \mathrm{s}$, poderemos notar o forte diálogo com a comunidade, a afirmação do grupo e as marcações temporais.

Aqui é Racionais MC's. Ice Blue, Mano Brown, KL Jay e eu, Edy Rock

- E aí Mano Brown, certo?

- Certo não está né mano. E os inocente? Quem os trará de volta?

- É, a nossa vida continua, quem se importa?

- A sociedade sempre fecha as portas mesmo, cara. E aí Ice Blue?

Pânico na zona sul - CD Holocausto urbano (1990)

Mil novecentos e noventa e dois. A juventude negra agora tem voz ativa Viemos mostrar que a sabedoria de rua vale muito

E não se aprende nas escolas e tal

Das ruas de São Paulo pro mundo: Racionais

Voz ativa (versão rádio) - CD Escolha o seu caminho (1992)

Mil novecentos e noventa e três

Fudidamente voltando

Racionais

Usando e abusando da nossa liberdade de expressão

Um dos poucos direitos que o jovem negro ainda tem nesse país

Você está entrando no mundo da informação, autoconhecimento, denúncia e diversão

Esse é o raio $X$ do Brasil, seja bem-vindo.

Introdução - CD Raio X Brasil (1993)

Deus fez o mar, as árvore, as criança, o amor

O homem me deu a favela, o crack, a trairagem, as arma, as bebida, as puta $\mathrm{Eu}$ ?

Eu tenho uma bíblia velha, uma pistola automática, um sentimento de revolta Eu tô tentando sobreviver no inferno

Genesis (intro) - CD Sobrevivendo no inferno (1998) ${ }^{13}$

\footnotetext{
${ }^{13}$ Na música de abertura desse álbum, o diálogo com a comunidade não é realizado de forma tão imediata. A primeira faixa do disco, Jorge da capadócia, do compositor Jorge Ben Jor, é cantada como música incidental sem acréscimo de letra por parte dos rappers. A segunda faixa e início da terceira cumprem um pouco essa função introdutória usualmente utilizada nos discos do grupo. A segunda, também denominada "intro", chama-se Genesis, título significativo tendo em vista a temática religiosa que perpassa todo o álbum. É somente na faixa seguinte, Capítulo 4, versículo 3, que escutamos a voz de Primo Preto enviar um recado mais direto ao ouvinte: "Sessenta por cento dos jovens de periferia sem antecedentes criminais já sofreram violência policial. A cada quatro pessoas mortas pela polícia três são negras. Nas universidades brasileiras apenas dois por cento dos alunos são negros. A cada quatro horas um jovem negro morre violentamente em São Paulo. Aqui quem fala é Primo Preto, mais um sobrevivente".
} 


\section{Benção mãe}

Estamos iniciando nossas transmissões

Essa é a sua rádio Êxodos

Hey, hey, vamo acordar, vamo acordar

Porque o sol não espera, demorou, vamo acordar

O tempo não cansa

Ontem à noite você pediu, você pediu uma oportunidade, mais uma chance

Como Deus é bom, né não nego?

Olha aí, mais um dia todo seu

Céu azul loco hein?

Vamo acordar, vamo acordar

Agora vem com a sua cara, sou mais você nessa guerra, a preguiça é inimiga da vitória, o fraco não tem espaço e o covarde morre sem tentar.

Não vou te enganar, o bagulho tá doido, ninguém confia em ninguém,

Nem em você, os inimigos vêm de graça, é a selva de pedra, ela esmaga os humildes demais,

Você é do tamanho do seu sonho, faz o certo, faz a sua, vamo acordar, vamo acordar,

Cabeça erguida, olhar sincero, tá com medo de quê?

Nunca foi fácil, junta os seus pedaços e desce pra arena, mas lembre-se:

Aconteça o que aconteça, nada como um dia após o outro dia

Sou + você. CD Nada como um dia após o outro dia (chora agora) (2002)

É tru, Racionais tá aí de novo, morô?

E os caras há mili ano na parada, pode crê,

Os cara representa a favela do começo ao fim,

Mas aí, é muita treta hein? É ideia de mil grau no bagulho.

De volta à cena. CD Nada como um dia após o outro dia (ri depois) (2002)

O posicionamento político de se dirigir diretamente ao público faz com que, significativamente, o rap seja o único gênero no qual os agradecimentos estão nas próprias músicas e não somente no encarte do $\mathrm{CD}$. Além disso, frequentemente, o $\mathrm{MC}$ menciona em suas canções nomes de amigos e lugares de seu cotidiano. É uma aproximação entre autor e ouvinte que ocorre de maneira muito natural. Música feita na periferia, para a periferia. Não é à toa que o rap nacional desenvolveu um forte sistema de produção cultural independente da grande mídia e sempre ligado às rádios comunitárias e apresentações em bairros pobres dos grandes centros urbanos.

Algo interessante pode ser observado no álbum Nada como um dia após o outro dia (RACIONAIS MC'S, 2002). Após a faixa Trutas e quebradas (na qual os rappers agradecem amigos e comunidades), temos a canção Da ponte pra cá, na qual ouvimos um trecho inicial falado em que um locutor de rádio envia agradecimentos e dedicatórias de pessoas de uma comunidade para habitantes de outros bairros periféricos, prática muito comum nas programações das rádios comunitárias 
brasileiras. Assim, além do grupo enviar seu próprio recado para as comunidades, há também espaço (ou a simulação artística desse espaço) para os ouvintes trocarem mensagens entre si, demonstrando o quanto a comunicação e a identificação do rap com as vozes da periferia são fundamentais no universo do hip hop.

A força da comunicação com o público está igualmente marcada na própria trajetória artística dos Racionais $\mathrm{MC}^{\prime}$, no que se refere ao nível de coloquialidade de suas letras. Como os próprios rappers afirmam, havia no início de sua carreira uma formalidade maior em relação à escolha lexical. As construções verbais se afastavam da coloquialidade para que se evitasse um registro linguístico ordinário. Essa atitude artística representava então um importante posicionamento político para o grupo. Aos poucos, no entanto, os integrantes deixam de lado esse registro mais formal e passam a incorporar a fala cotidiana em suas canções.

Situações violentas são narradas com "palavras de rua mesmo", um recurso que veio sendo conquistado a cada disco, conforme os rappers já disseram em mais de uma entrevista (inicialmente o grupo queria "ser intelectual, falar umas palavras difíceis", com "medo de ser mal interpretado, medo da música ser vulgar"). Também a sintaxe popular é empregada contra o preconceito linguístico e a favor da comunicação com a periferia (GARCIA, 2003, p.177)

A adoção de uma linguagem mais próxima da fala cotidiana, com a incorporação de gírias antes evitadas, por exemplo, representa certamente um importante posicionamento político. Aliás, observamos até mesmo que a ligação do público com o grupo cresce significativamente na medida em que a linguagem empregada chega ao ouvinte de maneira mais coloquial e familiar. A comunicação se fortalece. Assim, notamos, sem dúvida, a existência de um amadurecimento artístico desses cancionistas observado, sobretudo, a partir do álbum Raio X Brasil (1993). Nos discos anteriores, o emprego de termos da linguagem culta e a eliminação de gírias presentes na língua falada eram procedimentos utilizados para que suas obras não fossem confundidas com discursos vulgares e sem valor. Como se, assim, a produção pudesse ganhar aspecto de obra, já que a formalidade linguística poderia dar relevância às suas criações. É curioso notar que, a partir de Raio X Brasil, ao mesmo tempo em que a coloquialidade passa a ser incluída nas letras, os versos tornam-se formalmente mais trabalhados, nas sonoridades dos vocábulos e nas configurações rítmicas dadas aos textos verbais. 
Mas essa tendência figurativa não atua somente no sentido de aproximar o rapper de seu público. Ela também proporciona uma aproximação entre o compositor e o intérprete. No rap, o trabalho do cantor e o do letrista são esferas praticamente indissociáveis, pois não há intérprete que não cante suas próprias criações. O impulso figurativo explicita um modo de dizer, a dicção de cada MC. Constatamos uma maior presença da individualidade verbal de cada artista e essa maneira de entoar muitas vezes representa a própria composição. A ausência de notas musicais estáveis na sua melodia também colabora para isso, já que explicita o uso do registro da fala, chamando a atenção do ouvinte para um modo de dizer muito individualizado. Assim, interpretar uma canção de Mano Brown pode tornar-se uma tarefa um tanto complicada. Se em outros gêneros musicais é muito frequente a separação entre a figura do intérprete e a do compositor, no rap, ao contrário, pode-se afirmar que letrista e cantor se confundem praticamente na totalidade das situações.

A figurativização é tão marcante que pode provocar até mesmo uma fortíssima sensação de realidade. O ouvinte, ao perceber que os versos cantados estão próximos da linguagem do cotidiano, passa a considerá-los como verdadeiros. Esse aspecto é extremamente valorizado no universo do hip hop. O efeito de verdade das letras de rap sempre fez parte de sua fruição, pois, como já mencionamos acima, ela é fruto direto das experiências vividas pelas comunidades pobres. Como o rap sempre esteve ligado aos artistas da periferia, entendemos o porquê de tanta polêmica quando surgem no mercado $\mathrm{MC}^{\prime} \mathrm{s}$ pertencentes a classes sociais mais abastadas. A legitimidade de cantar a pobreza não é dada a qualquer artista. Por outro lado, essa confusão entre a composição e o mundo real gera, por vezes, fatos inusitados. No início de 2014, o jornal The New York Times publicou matéria a respeito do uso de letras de rap em processos judiciais nos EUA. As canções são usadas por promotores como provas de envolvimento de rappers em crimes diversos.

As letras e vídeos de rap estão aparecendo como provas nas salas de audiência de todo o país com regularidade alarmante. No ano passado, a Associação Americana das Liberdades Civis de Nova Jersey descobriu que em 18 processos nos quais várias cortes consideraram a admissibilidade do rap como evidência, as letras foram permitidas em quase 80 por cento das vezes (...) Stuart Fischoff, psicólogo da Universidade Estadual da Califórnia, Los Angeles, conduziu um estudo no final da década de 1990 para medir o impacto das letras do gangsta rap nos jurados. Os participantes receberam 
informações biográficas básicas de um hipotético negro de 18 anos, mas apenas alguns receberam um grupo das suas letras de rap violentas e sexualmente explícitas. Os participantes que leram as letras ficaram significantemente mais propensos a acreditar que o homem era capaz de cometer um assassinato do que os que não leram (NIELSON, 2014)

Obviamente, não podemos esquecer que, por trás dessas medidas judiciais, há claramente um teor discriminatório em relação aos indivíduos acusados. Isto é, há questões sociais aí implicadas que também influem no uso equivocado das letras das canções como provas de atos criminosos. No entanto, acreditamos que não seja apenas pelo fato de o rap retratar o universo da criminalidade que frequentemente autoridades associam o conteúdo das letras ao mundo real. Certamente, a forma da canção, predominantemente entoativa, colabora de maneira significativa para que se aumente essa impressão de realidade. Essa é, aliás, uma característica importantíssima para o gênero, na medida em que quanto maior for o seu efeito de verdade, maior será a força da sua denúncia. Nesse sentido, a fusão entre a figura do bandido e a figura do rapper é muito eficiente. O grupo Racionais $\mathrm{MC}^{\prime}$ s, por exemplo, em muitas de suas canções, costuma utilizar a comparação poética entre o ato criminoso e a atividade artística. É como se Mano Brown empregasse o mesmo grau de violência do assaltante que ataca a sua vítima para agredir a elite brasileira.

Meu estilo é pesado e faz tremer o chão

Minha palavra vale um tiro... eu tenho muita munição

(...)

Uni-duni-tê, eu tenho pra você

Um rap venenoso ou uma rajada de PT

Capítulo 4, versículo 3 - CD Sobrevivendo no inferno (1998)

Esse tipo de imagem poética possui até mesmo uma tradição histórica. Christian Béthune, em seu livro Le rap: une esthétique hors la loi, faz interessantes aproximações entre a história do rap e a história do jazz norte-americano. Um dos pontos de contato entre os dois gêneros artísticos é, segundo o autor, essa frequente comparação entre o ato musical e o uso agressivo de uma arma: “O músico de jazz recentemente comparou o seu instrumento a um machado e a sonoridade que tirava dele ao gume afiado de uma faca; nas mãos do $\mathrm{MC}$, o microfone se torna uma arma, e as palavras saem de sua garganta como tiros mortais" (BÉTHUNE, 1999, p.71). 
A presença da figurativização no rap também pode provocar outras questões polêmicas. Primeiramente, ainda que de forma geralmente ingênua, discutese a validade da sua condição enquanto gênero musical. Pelo fato de o cantor adotar o registro próximo da fala e não estabilizar a melodia com notas musicais, disseminouse a ideia de que o rap nada mais é do que a declamação de uma letra sobre uma base rítmica. Não nos interessa aqui determinar se o rap é ou não é um gênero musical, pois o conceito de categoria musical pode variar de cultura para cultura, de época para época. Somente devemos constatar que grande parte dos ouvintes está predominantemente acostumada com a audição de música tonal (melodia acompanhada por acordes e formada por alturas estáveis). Por isso, quando o público se depara com novos gêneros como o rap e o funk carioca ou com peças eruditas de compositores contemporâneos (que trabalham mais com os aspectos rítmicos, texturais e timbrísticos do que com o tonalismo), o estranhamento é inevitável. No caso do rap, esse estranhamento decorre, sobretudo, dessa sua proximidade com a fala.

Outra questão interessante decorrente dessa propensão figurativa é a constituição da identidade do gênero. Afinal, o que é o rap? Podemos dizer que esse tipo de canção apresenta elementos sonoros muito heterogêneos: falas diretas sem nenhuma musicalização, frases verbais ritmadas, refrãos cantados com alturas e padrões de duração estáveis, acompanhamento musical do DJ, samples de canções de outros autores etc. Dessa maneira, como poderíamos defini-lo? É rap apenas o canto ritmado do $\mathrm{MC}$ ou todo esse complexo universo sonoro? Como vimos, para o ouvinte comum, o que primeiro chama a atenção é o peso da entoação na relação entre a melodia e a letra. Isso é o que o distingue de outros universos cancionais. Assim, geralmente se entende como rap somente o canto falado do $\mathrm{MC}$, sem considerar os trechos cantados com alturas definidas. Essa posição, no entanto, é questionável na medida em que há exemplos nos quais o próprio MC varia o grau de musicalização da letra e até mesmo chega a estabilizá-la fortemente, como vimos em V.L. Parte 2, na melodia da voz de Mano Brown. Melhor dizendo, podemos perceber que a identidade do rap possivelmente se constrói a partir da convivência entre os processos ligados à fala e os processos de musicalização. Aliás, como em qualquer canção. Retomando o fragmento de Walter Garcia já comentado anteriormente: 
Ora, se o propósito do Racionais é passar uma mensagem crítica por meio da letra, a figurativização é o recurso mais adequado para isso. E o rap é o estilo de canção no qual esse recurso é mais essencial, pois a melodia do rap se constrói apenas pelo ritmo, enquanto as notas musicais são substituídas pela sonoridade da letra (entoação, rimas, assonâncias, aliterações) e pelo timbre do rapper (o timbre sugere a altura da emissão de acordo com o fundo musical). Fundamentalmente, o jogo rítmico entre a voz e o acompanhamento é a garantia de que cantar rap não é o mesmo que declamar um poema sobre um fundo musical: o rap quer passar uma ideia sem deixar de envolver todo o corpo do ouvinte (GARCIA, 2003, p.59)

Há, no texto acima, uma evidente tensão entre a fala e a música. Se, por um lado, o autor afirma que a figurativização é o seu processo essencial, por outro, destaca a presença do ritmo, da sonoridade da letra e da relação musical entre o ritmo do acompanhamento e o recorte das frases verbais. Até mesmo a questão corporal, mais ligada ao processo musical, aparece: “O rap quer passar uma ideia sem deixar de envolver todo o corpo do ouvinte". Trata-se, no entanto, de um conflito muito natural no âmbito do hip hop, presente desde sua mais remota origem. Basta pensarmos na oposição entre a fala do MC e a música do DJ. Como já comentamos, os equipamentos de som eram levados para as ruas nas festas do Bronx com o propósito de suscitar a dança. Afinal, os discos executados eram de música dançante: funk, soul e reggae. E ao mesmo tempo, no meio dessa regularidade musical havia o momento em que se falava com o público com o auxílio do microfone. É interessante sublinhar que, inicialmente, a pessoa responsável por tocar as músicas também falava ao microfone, quando os papéis de DJ e MC eram realizados por um único indivíduo. A tensão estava circunscrita a um só sujeito. Ao longo do tempo, pela dificuldade de desempenhar essas duas funções simultaneamente, elas passam a ser executadas por pessoas distintas. Enfim, constatamos que a coexistência entre a música/dança e a fala é uma característica muito presente no universo do rap. Se há, por um lado, a importância do entendimento da mensagem do $\mathrm{MC}$, por outro, há a fruição musical do acompanhamento do DJ que pode fazer com que o ouvinte se distancie ou se aproxime dessa mensagem. No rap, essa questão está sempre colocada. Sobre Diário de um detento, afirma Walter Garcia: “Já a dignidade e o corpo são resgatados, nessa canção, por um balanço que favorece mais o entendimento das palavras do que a dança. A rigor, a periferia não dança Racionais: canta junto, dramatiza a letra e balança o corpo" 
(GARCIA, 2007, p.186). A musicalização do rap não pode ser excessiva a ponto de prejudicar a compreensão do texto, ou melhor, de chamar mais atenção do que ele. A dança não pode ser exagerada, pois ela não é o seu intuito principal. Balançar demasiadamente o corpo poderia significar a falta de envolvimento do público com o conteúdo da letra. No entanto, notamos que, por vezes, a mensagem do texto pode chegar ao ouvinte mesmo sem o entendimento integral das palavras. Isto é, apenas pelo gesto do rapper, por sua atitude, a plateia consegue apreender intuitivamente e corporalmente o seu significado. A entoação de Mano Brown, carregada de agressividade, por si só já nos possibilita captar o teor do seu recado. Nesse sentido, mesmo quando escutamos uma canção em língua estrangeira com a qual não temos familiaridade, percebemos o sentido geral do texto apenas pelo modo como o cantor entoa a letra. Por fim, é relevante comentar que Garcia identifica entre os próprios cantores do grupo Racionais $\mathrm{MC}^{\prime}$ s uma variação em relação à presença da entoação. Segundo o autor, o canto do rapper Ice Blue apresenta-se mais musicalizado do que a interpretação de Mano Brown: “O acompanhamento feito por KL Jay orienta as performances de Mano Brown, canto falado mais próximo da fala e do intelecto, e de Ice Blue, canto falado mais próximo do canto e da dança" (GARCIA, 2007, p.196). Assim, constatamos que a tensão entre a fala e a música é algo que está presente no rap em diferentes níveis.

Nesse artigo, mais do que constatar a simples presença da entoação da fala no rap (algo que parece ser óbvio para o ouvinte mais desavisado), desejávamos analisar os seus diferentes modos de manifestação, desde a inserção de falas diretas, sem qualquer preocupação de estabilidade, até o texto ritmado e musicalizado do rapper. Em relação ao canto do $\mathrm{MC}$, ao examinarmos grande parte da produção do rap brasileiro, pudemos constatar que todos apresentam significativa uniformidade rítmica: ora observamos a divisão regular da letra em quatro semicolcheias, ora a divisão alternada com figuras pontuadas e simples (longas e breves). Além disso, verificamos que a velocidade da pulsação se situa geralmente entre 73 e 96 bpm. Vimos que essa configuração melódica uniforme, além do fato de o cantor emitir com o registro próximo ao da voz falada, pode ser a razão pela qual o ouvinte não é capaz de identificar motivos musicais relevantes. Nesse sentido, escutaríamos o rap como um 
bloco homogêneo com menor estabilização musical. Ou seja, embora as sílabas da letra sejam organizadas regularmente no tempo, essa regularidade quase absoluta faz com que, paradoxalmente, o ouvinte não a perceba. Observamos igualmente ocorrências muito interessantes em relação ao parâmetro altura. Notamos que, por vezes, o MC estabiliza notas musicais ou altera a região de frequência e que esse fenômeno pode corresponder a uma tensividade exigida pelo conteúdo da própria letra. É quando o canto situado em região mais aguda nos dá indício de uma fala exasperada, de uma emissão mais intensa e agressiva. Como comentamos acima, pudemos igualmente demonstrar que a força política do rap se encontra na sua específica linguagem cancional e que o processo figurativo, por sua proximidade em relação ao registro da língua oral, mostra-se como o mais adequado ou natural para a transmissão das mensagens dos $\mathrm{MC}^{\prime}$ s. A desigualdade social estimula a contestação e esse questionamento é mais eficiente quando realizado por meio da figurativização. A proximidade com a fala garante o seu efeito de verdade, e, consequentemente, a força de sua denúncia. Além disso, vimos o quanto esse processo cancional se relaciona a aspectos tão característicos do hip hop. Por um lado, proporciona a aproximação entre o artista e o público, que dividem o mesmo registro de voz. Por outro, entre o compositor e o intérprete, já que a predominância figurativa, ao explicitar um modo de dizer (a dicção de cada MC), produz uma individualidade verbal e esse modo de entoar muitas vezes constitui a própria composição.

\section{Referências}

BÉTHUNE, Christian. Le rap: une esthétique hors la loi. Paris : Éditions Autrement, 1999.

BUARQUE, Chico. Entrevista ao jornal Folha de São Paulo. Folha de São Paulo, Caderno Ilustrada. São Paulo, 26 dez. 2004.

GARCIA, Walter. Diário de um detento: uma interpretação. In: NESTROVSKY, Arthur (org.). Lendo música, 10 ensaios sobre 10 canções. São Paulo: Publifolha, 2007.

GARCIA, Walter. Ouvindo Racionais MC's. Teresa - revista de literatura brasileira. São Paulo: Editora 34, 2003. 
KEHL, Maria Rita. A fratria órfã: o esforço civilizatório do RAP na periferia de São Paulo. In: KEHL, Maria Rita (org.). Função fraterna. Rio de Janeiro: Relume Dumará, 2000.

NIELSON, Erik e KUBRIN, Charis. Letras de rap em julgamento nos Estados Unidos. O Globo, 2014. Disponível em: <http://oglobo.globo.com/mundo/letras-de-rap-emjulgamento-nos-estados-unidos-11318331>. Acesso em: 25 dez. 2016

RACIONAIS MC'S. Nada como um dia após o outro dia. Cosa Nostra, 2002. CD.

RACIONAIS MC'S. Sobrevivendo no inferno. Cosa Nostra, 1998. CD.

RACIONAIS MC'S. Escolha o seu caminho. Cosa Nostra, 1992. CD.

ROSE, Tricia. Black Noise: Rap music and Black Culture in Contemporary America. Middletown: Wesleyan, 1994.

SABOTAGE. Rap é compromisso. Cosa Nostra, 2001. CD.

TATIT, Luiz. O Cancionista. São Paulo: Edusp, 2002.

TEPERMAN, Ricardo Indig. Tem que ter suingue: batalhas de freestyle no metrô Santa Cruz. Tese (Mestrado em Ciências Sociais) - FFLCH-USP, São Paulo, 2011.

THAÍDE E DJ HUM. Hip hop cultura de rua. Eldorado, 1988. CD. 